\title{
Ideal Japanese Class for Taiwanese High School Students: A Gender Comparison
}

\author{
Abolfazl Shirban Sasi ${ }^{1, *} \&$ Toshinari Haga ${ }^{1}$ \\ ${ }^{1}$ Department of Applied Foreign Languages, TransWorld University, Taiwan \\ *Correspondence: Department of Applied Foreign Languages, TransWorld University, Taiwan. Tel: 886-919456970. \\ E-mail: Pictologics@gmail.com
}

Received: September 28, 2018 Accepted: November 14, $2018 \quad$ Online Published: December 20, 2018

doi:10.5430/wje.v8n6p147 URL: https://doi.org/10.5430/wje.v8n6p147

\begin{abstract}
Learning Japanese has become very common amongst Taiwanese high school and university students, ranking the second most sought for language. A concise study of the likeable activities in a typical language class for the Taiwanese students seems to be quite useful. Therefore, the present study has concentrated on the senior high school students' opinion about the ideal Japanese class. Subjects in this research were 478 students (181 boys, and 297 girls) in nine private schools in three counties. The instrument was a 10-item multiple-choice Chinese questionnaire based on Littlewood (2010). The findings illustrated that females and males had similar opinions concerning the communicative language activities in an ideal Japanese class. They revealed much more differences related to non-communicative activities, though. Moreover, both boys and girls displayed the highest interest in a relaxed class atmosphere, and the lowest interest in the usage of smartphones in the activities in the class.
\end{abstract}

Keywords: activities, communicative, ideal, Japanese language

\section{Introduction}

Studying the Japanese language and culture has been growing constantly around the globe. One way this can be revealed is by looking at the statistics concerning the number of students who have studied in Japan. For instance, the Japanese Ministry of Education has stated that the number of foreign students studying in Japan in 2005 was 121,812, compared with 53,847 in 1995, and 10,428 in 1983 (MEXT, 2006, p.7). Moreover, evidence of the constant interest in Japanese language can be found by examining the number of students who have taken the Japanese Language Proficiency Test (JLPT) each year. This standard test is an internationally recognized test of Japanese skills and has been administered since 1984 by Japan Educational Exchanges and Services in Japan, and by the Japan Foundation and its associated organizations in several other countries. Table 1 shows the figures in the past years since the beginning (JLPT, 2017).

Table 1. Japanese Language Proficiency Test (JLPT) number of examinees in the past years

\begin{tabular}{cccccccccccc}
\hline Year & 1984 & 1985 & 1986 & 1987 & 1988 & 1989 & 1990 & 1991 & 1992 & 1993 & 1994 \\
\hline $\begin{array}{c}\text { No. of } \\
\text { Examinees }\end{array}$ & 7,019 & 13,069 & 17,532 & 21,240 & 26,855 & 35,609 & 42,787 & 58,494 & 68,565 & 80,713 & 82,327 \\
$\quad$ Year & 1995 & 1996 & 1997 & 1998 & 1999 & 2000 & 2001 & 2002 & 2003 & 2004 & 2005 \\
$\quad$ No. of & 88,165 & 96,140 & 104,079 & 130,385 & 166,575 & 201,021 & 227,593 & 242,331 & 269,617 & 302,198 & 356,244 \\
$\begin{array}{c}\text { Examinees } \\
\quad \text { Year }\end{array}$ & 2006 & 2007 & 2008 & 2009 & 2010 & 2011 & 2012 & 2013 & 2014 & 2015 & 2016 \\
$\quad$ No. of & 437,360 & 523,958 & 559,056 & 768,113 & 607,972 & 608,157 & 572,169 & 571,075 & 594,682 & 652,519 & 755,802 \\
Examinees & & & & & & & & & & & \\
\hline
\end{tabular}

As can be seen in Table 1, the number of examines underwent a steady growth since 1984 to 2008. This increase of the numbers accelerated significantly in the year 2009; however, it experienced either no growth or decline in the years afterwards until 2015. Again, we can see a substantial increase in numbers in 2016.

Then as for the Taiwanese students, we might accept that nowadays various web applications can be indicators of how much they would like to learn Japanese or any other language. For example, in tandem with the present study, 
the authors scrutinized "Taiwan Language Exchange - Taiwanese Language Partners" (a web network that assists users to make friends with the natives of various languages in order to exercise and learn a particular tongue). Virtually all the most important and official languages are listed on this site. However, in order to be brief, in addition to Japanese, the authors inspected the six present official and working languages of the United Nations which are Arabic, Chinese, English, French, Russian, and Spanish; as well as the official languages of the ASEAN countries- some of the most crucial trade partners of Taiwan (Shirban Sasi, 2014) - namely, Burmese, Cambodian, Filipino (Tagalog), Indonesian, Lao, Malay, Thai, and Vietnamese. Finally, the authors also added German, and Korean based on personal observations. Thus, as of April $6^{\text {th }}$, 2018, the statistics on 16 highly desired languages by the Taiwanese are tabulated and ranked in Table 2.

Table 2. Languages that Taiwanese Like to Learn Most

\begin{tabular}{ccc}
\hline Rank & Language & Number \\
\hline 1 & English & 48270 \\
2 & Japanese & 12941 \\
3 & Korean & 6248 \\
4 & French & 5819 \\
5 & Spanish & 4665 \\
6 & German & 4180 \\
7 & Russian & 925 \\
8 & Thai & 846 \\
9 & Vietnamese & 543 \\
10 & Arabic (Middle Eastern) & 231 \\
11 & Filipino (Tagalog) & 207 \\
12 & Indonesian (Bahasa) & 203 \\
13 & Cambodian (Khmer) & 175 \\
14 & Burmese & 153 \\
15 & Malay (Bahasa Malaysia) & 109 \\
16 & Lao & 14 \\
\multicolumn{2}{c}{} \\
\hline
\end{tabular}

Note: Total is not accumulative.

As already stated in a previous authors' similar study (Shirban Sasi \& Haga, 2018), it must be noted that the number 85529 , that is the sum, is not an accumulation of the numbers referred to the other languages on this list. That is because many web users have selected more than one language to learn. Thus, as illustrated in Table 2, after English, Japanese is by far the most sought for language to learn among Taiwanese people. In addition, a more scrutiny about this website and the users' pictures and their text messages shows that they are mostly either in their teens or early twenties. We can conclude that the present examination which aims at discovering the ideal Japanese class from the Taiwanese students' point of view may well picture as to what kind of Japanese language classroom activities can help the Taiwanese language learners enhance their efforts in learning and, ultimately, support them gain the objectives of learning the Japanese skills.

\section{Review of Literature}

To the best knowledge of the authors, there has not been a similar research study which has targeted ideal classrooms for learners of Japanese. Several studies, however, have been conducted addressing the same issue concerning learners of English, such as Baleghizadeh \& Karamzade, 2017; Littlewood, 2010; Rao, 2002; Sampson, 2010; Shirban Sasi \& Haga, 2018, and Spratt, 2001. Thus, the results of the current study might prove very useful for the future studies in this particular domain.

On the other hand, if we associate the ideal Japanese class activities with students' motivation in studying this language in these classes, then there are substantial studies in the literature. For instance, Keaney and Mundia (2014) studied the Japanese learners' motivation and its effects on the teaching effectiveness among the students of University of Brunei Darussalam. They found out that there are five important motivational factors; namely, interest in the target language, the associated pop culture, the people, potential job opportunities, and self-satisfaction. Smith (1996) hypothesizes that social factors may have significant and long-lasting negative effects on learning Japanese 
which might lead the students to give up attempts to overcome linguistic or intercultural barriers, and thus, halting progress in both areas. In another study, Liu and Su (2016) found out that the Chinese participants have a higher level of motivation in learning Japanese than in learning English. Also, students' past language learning involvements affected their difference in motivation of studying English and Japanese. Comparing these two languages, the authors assume that most of the Chinese participants in their study had positive attitudes towards learning Japanese which may contribute to their rather high motivation. Thus, these students were able to implement effective motivated activities to self-regulate their Japanese learning.

Nonetheless, there are extensive studies comparing male and female language students. For instance, Hans and Bleses (2003) studied 85 children born and raised in Funen, Denmark. The study showed that firstly, children behaved like the typically assumed normal pattern in that females observe more standard features when using the language; and secondly, that for Danish children, differences in gender took place at an earlier age compared to British and American ones. Yilmaz (2010) studied children's gender differences regarding learning strategies. The findings revealed that girls use more operational strategies than boys do. Moreover, Cengizhan (2011) found out that meta-cognitive strategies are the highest recurrently used word learning strategies by boys; whereas, determination strategies are the most frequently used among girls. However, according to Allendorfer et al. (2012), differences in language-related topics are infrequent when girls and boys who are matched for age and performance are straightly being compared. Then, Shirban Sasi (2012) found no significant difference among male and female students when comparing their English vocabulary intake in a Malaysian primary school students with regard to their response to two different methods of teaching English. Nevertheless, the study by Baleghizadeh \& Karamzade, (2017) concerning Iranian EFL learners' perceptions of classroom language activities, proved that 1) girls demonstrated stronger preference towards form-oriented lessons; and 2) boys and girls revealed no significant difference in their attitudes with reference to control-oriented and communication-oriented lessons.

\section{Materials and Method}

\subsection{Introduction}

The purpose of the data gathered in the current research was to explore the ideal Japanese class based on the view point of the senior high school students in Taiwan. The probable differences in opinion among boys and girls have also been examined in this study.

\subsection{Participants}

Initially, 495 senior high school students from 9 private high schools in three counties of Chiayi, Yunlin, and Taichung (located almost in the center of Taiwan) took part in this study. However, since some questionnaires were filled out incompletely, they were crossed out from the analysis. Consequently, 478 students (181 boys, and 297 girls) were accounted for.

\subsection{Instrument}

The authors modified a 10-item multiple choice Chinese questionnaire based on the English version developed by Littlewood (2010). Numerous English versions of the original questionnaire have been used ever since by other researchers; for instance, Baleghizadeh \& Karamzade (2017). Littlewood developed this questionnaire based on thematic analysis he conducted when doing a series of interviews in his research. He asserts that the first four items on the questionnaire are "communicative", whereas, the other items, excluding item 8, are "non-communicative". According to him, item 8 is neutral and might be considered to belong to either group in different contexts, Littlewood (2010).

The authors have made the following adjustments to the original questionnaire in the current study:

- The most significant revision was to rewrite all the questions into declarative, directive phrases rather than the declarative phrases used before. The reason was to avoid misinterpretation on part of the students. For instance, the third item "There is plenty of active discussion." was changed to "There must be plenty of active discussion."

- The authors assumed that the $7^{\text {th }}$ item on the original questionnaire was very similar to the $5^{\text {th }}$ and $9^{\text {th }}$ items in that they all concerned teaching grammar. Then, this question was replaced with a question about the deliberate usage of smartphones in the class activities permitted/encouraged by the Japanese teacher. This decision was partly due to the over use of smartphones by the Taiwanese students in many classes the researchers had. 
Subsequently, in order to be certain that all subjects in this study comprehend each item accurately, the revised English questionnaire (APPENDIX) was translated into Mandarin Chinese by an experienced Taiwanese English teacher, and later administered to the participants.

\subsection{Research Questions and Hypotheses}

As stated earlier, the questionnaire items which were used in the current study may be listed into two general dichotomies of communicative and non-communicative activities. Nevertheless, in this study, the authors have examined and investigated each item of the questionnaire independently. The logic was that the authors presumed that each question could stand on its own and there was no need to group them together in certain categories. Subsequently, the following generic research question and hypothesis was applied for each of the 10 items on the questionnaire:

(n) - Is there any significant difference between the male participants' viewpoint on the ideal Japanese class defined in question (n) and that of the female participants?

$\mathrm{H}_{0}(\mathrm{n})$ - There is no significant difference between the male participants' viewpoint on the ideal Japanese class defined in question (n) and that of the female participants.

\section{Results}

The authors have used both descriptive and inferential statistics to analyze and discuss the data collected in this research. It is also worth noticing here that the notion of validity of using Likert scale data in parametric analysis is open to debate. Several scholars believe that the intervals between the Likert scale values are not equivalent; hence, any numerical values associated to them cannot be valid (for example, Jamieson, 2004). However, there are those (for example, Lubke \& Muthen, 2004) who assert that it is possible to validly use parametric tests for Likert scale data. The authors have followed the second group in the present study. Thus, the data have been used parametrically if required. The reason is even though the Likert scales intervals are not equal mathematically, if they are applied equally amongst subjects in a certain study, the data may show us some accurate indications of possible discrepancies. The Likert scales used in the present study were: strongly disagree (1); disagree (2); undecided (3); agree (4); and strongly agree (5).

\subsection{Overall Count of the Participants' Responses to Each Questionnaire Item}

Table 3 illustrates all the students' responses item by item. Furthermore, in order to have a better picture of the responses, the numbers have been converted into percentages, and then juxtaposed to each gender.

Table 3. Percentage of Responses to Each Item on the Questionnaire

\begin{tabular}{|c|c|c|c|c|c|c|c|c|c|}
\hline \multicolumn{2}{|c|}{ 1- A relaxed atmosphere } & (4) & & & & & & & \\
\hline M 58 & F 43.4 & M 28 & F 45.1 & M 13 & F 10.4 & M 0 & F 0.7 & M 1 & F 0.3 \\
\hline \multicolumn{10}{|c|}{ 2- Authentic materials } \\
\hline M 32 & F 23.9 & M 33.7 & F 42 & M 33 & F 32 & M 0.6 & F 2 & M 0.6 & F 0 \\
\hline \multicolumn{10}{|c|}{ 3- More active debates } \\
\hline M 28 & F 15.8 & M 37 & F 33 & M 33 & F 49 & M 1 & F 2.3 & M 0.6 & F 0 \\
\hline \multicolumn{10}{|c|}{ 4- More having fun } \\
\hline M 33.7 & F 25.2 & M 31.5 & F 34.3 & M 32 & F 37 & M 1.6 & F 3 & M 1 & F 0.3 \\
\hline \multicolumn{10}{|c|}{ 5- Exposure to more language rules } \\
\hline M 28 & F 18 & M 36.5 & F 46.8 & M 32 & F 34 & M 1 & F 0.7 & M 2 & F 0.3 \\
\hline \multicolumn{10}{|c|}{ 6- Correction of grammatical mistakes by the teacher } \\
\hline M 36 & F 31.6 & M 38 & F 49.8 & M 23 & F 18 & M 1 & F 0.3 & M 1.6 & F 0 \\
\hline \multicolumn{10}{|c|}{ 7- Students' autonomy in the class activities } \\
\hline M 23.7 & F 11.8 & \multicolumn{2}{|c|}{ M 24.3 (4) } & M 42.6 & F 48.8 & M 5.5 & F 3.3 & M 3.8 & F 0.3 \\
\hline
\end{tabular}


8- Emphasis on correct pronunciation

(5)

$\begin{array}{lrr}\text { M } 30 & \text { F } 27 & \text { M } 33.7\end{array}$

(5)

M 24.9

F $13 \quad$ M 28.7

(4)

F 44.8

(4)

10 - Usage of smart phones in the class activities

(5)

\section{24.3}

(4)

Note: $M=$ Males; F=Females; (5)=strongly agree; (4)=agree; (3)=undecided; (2)=disagree; (1)=strongly disagree

(3)
(2)
(3)

F 26.6 M 0

(2)

(1) $\mathrm{F} 0$

(1) M 39

F 49.8

M 5

F 4

M 2.2 F 0.7

(1)

(2) F $14 \quad$ M 3.3

Additionally, and in order to have a better understanding as to what situations/activities are favored most by either males or females, the responses have been parametrically calculated and ranked. The results are illustrated in Table 4.

Table 4. Most Ideal Activities Being Ranked and Compared

\begin{tabular}{|c|c|c|c|c|c|c|c|c|c|c|c|c|c|c|c|c|c|c|c|c|}
\hline \multirow{2}{*}{$\begin{array}{l}\text { Item } \\
\text { Likert }\end{array}$} & \multicolumn{2}{|c|}{ [1] } & \multicolumn{2}{|c|}{ [2] } & \multicolumn{2}{|c|}{ [3] } & \multicolumn{2}{|c|}{ [4] } & \multicolumn{2}{|c|}{ [5] } & \multicolumn{2}{|c|}{ [6] } & \multicolumn{2}{|c|}{ [7] } & \multicolumn{2}{|c|}{ [8] } & \multicolumn{2}{|c|}{ [9] } & \multicolumn{2}{|c|}{ [10] } \\
\hline & $\mathrm{M}$ & $\mathrm{F}$ & $\mathrm{M}$ & $\mathrm{F}$ & $\mathrm{M}$ & $\mathrm{F}$ & $\mathrm{M}$ & $\mathrm{F}$ & $\mathrm{M}$ & $\mathrm{F}$ & $M$ & $\mathrm{~F}$ & $M$ & $\mathrm{~F}$ & $\mathrm{M}$ & $\mathrm{F}$ & $\mathrm{M}$ & $\mathrm{F}$ & $M$ & $\mathrm{~F}$ \\
\hline 5 & 105 & 129 & 58 & 71 & 51 & 47 & 61 & 75 & 51 & 53 & 65 & 94 & 43 & 35 & 54 & 81 & 45 & 40 & 44 & 42 \\
\hline 4 & 50 & 134 & 61 & 125 & 67 & 97 & 57 & 102 & 66 & 139 & 69 & 148 & 44 & 106 & 61 & 133 & 52 & 95 & 17 & 35 \\
\hline 3 & 24 & 31 & 60 & 95 & 60 & 146 & 58 & 110 & 58 & 102 & 42 & 54 & 77 & 145 & 61 & 79 & 71 & 148 & 100 & 161 \\
\hline 2 & 0 & 2 & 1 & 6 & 2 & 7 & 3 & 9 & 2 & 2 & 2 & 1 & 10 & 10 & 0 & 4 & 9 & 12 & 14 & 41 \\
\hline 1 & 2 & 1 & 1 & 0 & 1 & 0 & 2 & 1 & 4 & 1 & 3 & 0 & 7 & 1 & 5 & 0 & 4 & 2 & 6 & 18 \\
\hline Sum & 799 & 1279 & 717 & 1152 & 708 & 1075 & 715 & 1132 & 701 & 1132 & 734 & 1226 & 649 & 1055 & 702 & 1182 & 668 & 1050 & 622 & 888 \\
\hline Rank & 1 & 1 & 3 & 4 & 5 & 7 & 4 & $5 \& 6$ & 7 & $5 \& 6$ & 2 & 2 & 9 & 8 & 6 & 3 & 8 & 9 & 10 & 10 \\
\hline
\end{tabular}

Note: $M=$ Males; $F=$ Females

As evident in Table 4, item 1 in the questionnaire has gained the largest number by males and females, while item 10 received the lowest by boys and girls equally. Moreover, item 6 gained the second highest number by both male and female participants. In addition, question 7 nearly received the second lowest number by both genders. Finally, in order to have a deeper understanding of the obtained results, suitable statistical tests have been employed that will be elaborated more in the following section.

\subsection{Statistical Tests Used for the Research Questions and Hypotheses}

A Pearson Chi-square test has been used for each questionnaire item. In the current study the two categorical variables for each question are as follows:

- Group (boys/girls)

- Participants' response to each item (strongly disagree/disagree/undecided/agree/strongly agree)

4.3 Procedure

The most essential assumption of Chi-square test is the "minimum expected cell frequency". Since in the current study, each of the 10 questionnaire items has been tested with a single Chi-square test, except for items number 7, 9, and 10, the other questions did not meet this assumption. To solve this problem, according to Clegg (1982) we should merge the neighbouring cells. Then, the researchers combined the groups (cells) of "strongly disagree", "disagree", and "undecided" for the other seven items in order to avoid violation of this assumption. Subsequently, a chi-square test was conducted for each of the 10 questionnaire items as listed on Table 5 below $(\alpha \leq .05)$. 
Table 5. Results Summary of the Chi-square Test for Each Item on the Questionnaire

\begin{tabular}{cccc}
\hline Question & $\begin{array}{c}\text { Pearson Chi-square } \\
\text { value }\end{array}$ & $\begin{array}{c}\text { Asymp. Sig. } \\
(2 \text {-sided })\end{array}$ & $\begin{array}{c}\text { Significant or } \\
\text { Non-significant }\end{array}$ \\
\hline 1 & 15.565 & .000 & Significant \\
2 & 4.795 & .091 & Non-significant \\
3 & 15.939 & .000 & Significant \\
4 & 4.017 & .134 & Non-significant \\
5 & 8.320 & .016 & Significant \\
6 & 6.935 & .031 & Significant \\
7 & 26.080 & .000 & Significant \\
8 & 6.280 & .043 & Significant \\
9 & 13.697 & .008 & Significant \\
10 & 13.859 & .008 & Significant \\
\hline
\end{tabular}

As evident in Table 5, the associated significance level of each chi-square test has been juxtaposed with its counterpart Pearson chi-square value. The results show that among the ten questionnaire items, only items 2 and 4 have been responded nearly alike (no significant difference seen) by males and females. That is, as for these two items, males and females have substantially similar viewpoints. Therefore, we might assert that for items 2 and 4 the null hypotheses (There is no significant difference between the male participants' viewpoint on the ideal Japanese class defined in questions 2 and 4, and that of the female participants.) cannot be rejected. This translates that both girls and boys had just about the same opinions towards each of these two language class activities. Then, as for items $1,3,5,6,7,8,9$, and 10 of the questionnaire, the difference between the male and female subjects has been significant, which means that they have significantly different opinions. Afterwards, to inspect the direction of this dissimilarity, the mean and sum of all the male and female students' responses to each item have been calculated parametrically based on the Likert scales values of 1 to 5 (Table 6).

Table 6. Calculated Likert Sum and Mean for Each Item on the Questionnaire

\begin{tabular}{|c|c|c|c|c|c|c|c|c|c|c|c|c|c|c|c|c|}
\hline & \multicolumn{2}{|c|}{$\mathrm{I} .1$} & \multicolumn{2}{|c|}{ I. 3} & \multicolumn{2}{|c|}{ I. 5} & \multicolumn{2}{|c|}{ I.6 } & \multicolumn{2}{|c|}{ I.7 } & \multicolumn{2}{|c|}{ I. 8} & \multicolumn{2}{|c|}{ I.9 } & \multicolumn{2}{|c|}{ I.10 } \\
\hline & M & $\mathrm{F}$ & M & $\mathrm{F}$ & M & $\mathrm{F}$ & M & $\mathrm{F}$ & M & $\mathrm{F}$ & M & $\mathrm{F}$ & M & $\mathrm{F}$ & M & $\mathrm{F}$ \\
\hline Sum & 799 & 1279 & 708 & 1075 & 701 & 1132 & 734 & 1226 & 649 & 1055 & 702 & 1182 & 668 & 1050 & 622 & 888 \\
\hline Mean & 4.41 & 4.30 & 3.91 & 3.61 & 3.87 & 3.81 & 4.05 & 6.77 & 3.58 & 3.55 & 3.87 & 3.97 & 3.69 & 3.53 & 3.43 & 2.98 \\
\hline Mean Results & \multicolumn{2}{|c|}{$\mathrm{M}>\mathrm{F}$} & \multicolumn{2}{|c|}{$\mathrm{M}>\mathrm{F}$} & \multicolumn{2}{|c|}{$\mathrm{M}>\mathrm{F}$} & \multicolumn{2}{|c|}{$\mathrm{F}>\mathrm{M}$} & \multicolumn{2}{|c|}{$\mathrm{M}>\mathrm{F}$} & \multicolumn{2}{|c|}{$\mathrm{F}>\mathrm{M}$} & \multicolumn{2}{|c|}{$\mathrm{M}>\mathrm{F}$} & \multicolumn{2}{|c|}{$\mathrm{M}>\mathrm{F}$} \\
\hline
\end{tabular}

Note: $M=$ Males; F=Females; $I=$ Item

As evident in Table 6, the male students favored questions 1, 3, 5, 7, 9, and 10 more than the females. Additionally, females favored items 6 , and 8 more than males. The results will be discussed more deliberately in the next section.

\section{Discussion}

The current paper revealed that female and male language learners have more common interest in Japanese communicative language activities than they do for non-communicative activities. We can deduce this because both genders showed no significant difference in items 2 and 4 (authentic material, and language games). This observation agrees with the results of Baleghizadeh \& Karamzade, (2017). The data of the present study also revealed that girls are more interested in activities in tandem with learning Japanese accurate pronunciation and grammar (items 6 and 8). This supports the first findings of the research by Hans and Bleses (2003) in that females have significantly higher standard features in their language use. In addition, exclusive of items 2 and 4, female and male participants revealed significant differences in their preference for Japanese language activities. This observation contradicts the findings of Shirban Sasi (2012) and Allendorfer et al. (2012) in which no significant differences between boys and girls were reported. Moreover, both female and male students expressed the lowest interest in using their smartphones in the class activities. This somehow contradicts the authors' personal observations during many years of teaching Taiwanese students. One probable cause may be that the students were shy admitting that they liked using their smartphones in the Japanese classes (despite the questionnaire being anonymous). Furthermore, both boys and girls similarly chose the lowest second rank for the activities which were independent of the teacher (item 7). This might be because of the teacher-centered education system in Taiwan. Lastly, almost all the participants were 
considerably more interested in a relaxed atmosphere in their Japanese classes which can suggest the necessity of eliminating, or at least reducing stress or potential uncomfortable circumstances that may emerge in any language classroom.

\section{Conclusion}

The present paper examined Taiwanese high school students' opinion about ideal teaching/learning activities in a Japanese class. Males and females revealed some common preferences, however, they had more significant differences. We assume that the results of this study and related observations in the future may become useful to education authorities or decision makers. Finally, we would like to recommend the following research topics for more scrutiny in future studies:

- Similar surveys with university students as research participants;

- Contrastive analysis between the ideal Japanese class activities as against the ideal English (or any other language) class activities;

- Using various types of interviews to find out the reasons why some particular activities are more interesting to students;

- More participants from other countries (or counties in Taiwan);

- Examining the effects of the students' Japanese proficiency level on the class activities they favor most;

- Comparing the opinions of different groups of participants with various ethnic/cultural backgrounds.

\section{References}

Allendorfer, J. B., Lindsell, C. J., Siegel, M., Banks, C. L., Vannest, J., Holland, S. K., et al. (2012). Females and males are highly similar in language performance and cortical activation patterns during verb generation. Cortex, 48(9), 1218-1233. http://dx.doi.org/10.1016/j.cortex. 2011.05.014

Baker, S. C., \& MacIntyre, P.D. (2000). The role of gender and immersion in communication and second language orientations. Language Learning, 50(2), 311-341. https://doi.org/10.1111/0023-8333.00119

Baleghizadeh, S., \& Karamzade, T. (2017). Iranian EFL learners' perceptions of various language activities in an ideal English class. MEXTESOL Journal, 41(1), 1-14.

Cengizhan, L. (2011). Vocabulary learning strategies: a case of Edirne Anatolian high school. Procedia Social and Behavioral Sciences, 15, 1870-1874. https://doi.org/10.1016/j.sbspro.2011.04.018

Clegg, F. (1982). Simple statistics: A course book for the social sciences. Cambridge: Cambridge University Press.

Grace, C. A. (2000). Gender differences: vocabulary retention and access to translations for beginning language learners in CALL. The Modern Language Journal, 84(2), 214-224. https://doi.org/10.1111/0026-7902.00063

Hans, J. L., \& Bleses, D. (2003). Gender differences in young children's speech: the acquisition of sociolinguistic competence. International Journal of Applied Linguistics, 13(2), 222-233. https://doi.org/10.1111/1473-4192.00045

Jamieson, S. (2004). Likert scales: how to (ab) use them. Medical Education, 38, 1212-1218. https://doi.org/10.1111/j.1365-2929.2004.02012.x

JLPT results announcements (2017). A summary of the results for the 2017 JLPT: Statistics for the last years. Retrieved in Nov. 2017 from http://www.jlpt.jp/e/statistics/archive.html

Kaushanskaya, M., Marian, V., \& Yoo, J. (2011). Gender differences in adult word learning. Acta Psychologica, 137, 24-35. https://doi.org/10.1016/j.actpsy.2011.02.002

Keaney, M., \& Mundia, L. (2014). Foreign language learners' motivation and its effects on their achievement: implications for effective teaching of students studying Japanese at University Brunei Darussalam. International Education Studies, 7(9), 122-135. http://dx.doi.org/10.5539/ies.v7n9p122

Littlewood, W. (2010). Chinese and Japanese students' conceptions of 'the ideal English lesson'. RELC Journal, 4l(1), 46-58. https://doi.org/10.1177/0033688210362622

Liu, Y. L., \& Su, L. Z. (2016). Different Motivations of Chinese Students Learning Japanese and English in Japan. Open Journal of Modern Linguistics, 6, 25-36. http://dx.doi.org/10.4236/ojml.2016.61003 
Lubke, G. H.; \& Muthen, B. O. (2004). Applying Multigroup Confirmatory Factor Models for Continuous Outcomes to Likert Scale Data Complicates Meaningful Group Comparisons. Structural Equation Modeling, 11, 514-534. https://doi.org/10.1207/s15328007sem1104_2

MacIntyre, P.D., \& Baker, S. C. (2002). Sex and age effects on willingness to communicate, anxiety, perceived competence, and L2 motivation among junior high school French immersion students. Language Learning, 52(3), 537-564. https://doi.org/10.1111/1467-9922.00194

MEXT [Ministry of Education, Culture, Sport, Science and Technology, Japan], (2006). Outline of the student exchange programs in Japan. Special Report. Student Services Bureau, Higher Education Division. Tokyo: MEXT

Ministry of Education. (2014). Education in Taiwan. Retrieved in Oct. 2017 from https://stats.moe.gov.tw/files/ebook/Education_in_Taiwan/2013-2014

Phakiti, A. (2003). A closer look at gender and strategy use in L2 reading. Language Learning, 53(4), 649-702. https://doi.org/10.1046/j.1467-9922.2003.00239.x

Rao, Z. (2002). Chinese students' perception of communicative and non-communicative activities in EFL classroom. System, 30(1), 85-105. http://dx.doi.org/10.1016/S0346-251X(01)00050-1

Sampson, R. J. (2010). Student-negotiated lesson style. RELC Journal, 41(3), 283-299. https://doi.org/10.1177/0033688210380555

Shehadeh, A. (1999). Gender differences and equal opportunities in the ESL classroom. ELT Journal, 53(4), 256-261. https://doi.org/10.1093/elt/53.4.256

Shirban Sasi, A. (2012). The effects of applying Pictologics (PLS) method on English vocabulary learning by Malaysian year six primary school students. Unpublished Ph. D. thesis, University Sains Malaysia, Malaysia.

Shirban Sasi, A. (2014). Iran and Asia: the New Stage of SMEs in Malaysia, Taiwan, China, and Japan. 2014 International Conference on Asian Regional Economy and Local Industry Development, TransWorld University, Douliu, Taiwan, Nov., 4-6.

Shirban Sasi, A., \& Haga, T. (2018). Taiwanese university students' expectations of ideal English class lessons. World Journal of English Language (WJEL), 8(1), 37-48. https://doi.org/10.5430/wjel.v8n1p37

Smith, R.C. (1996). Learning Japanese, from learners' points of view: affective and social factors in independent learning. In O. Kamata \& H. Yamauchi (Eds.), Nihongokyoiku, Ibunkakan Komyunikeshon (Japanese Language Teaching and Intercultural Communication). Tokyo: Bonjinsha.

Spratt, M. (2001). The value of finding out what classroom activities students like. RELC Journal, 32(2), 80-101. https://doi.org/10.1177/003368820103200206

Taiwan Language Exchange-Taiwanese Language Partners (2017) Retrieved Feb. 2018 from https://mylanguageexchange.com/Search.asp?selCountry $=90$

Varol, B., \& Yilmaz, S. (2010). Similarities and difference between female and male learners: Inside and outside class autonomous language learning activities. Procedia Social and Behavioral Sciences, 3, 237-244. https://doi.org/10.1016/j.sbspro.2010.07.038

Yang, Y. (2001). Sex and language proficiency level in color-naming performance: an ESL/EFL perspective. International Journal of Applied Linguistics, 11(2), 238-256. https://doi.org/10.1111/1473-4192.00016 


\section{APPENDIX The Ideal Japanese Lesson Questionnaire}

Sex: Male

$\square$ Female

Instruction: Please read each statement below carefully and choose your opinion regarding the characteristics of an ideal Japanese lesson. Please choose only one of (strongly agree, agree, undecided, disagree, strongly disagree) responses. Thank you.

\section{In my ideal Japanese lesson:}

1- The atmosphere must be relaxed.

strongly agree $\square \quad$ agree $\square \quad$ undecided $\square \quad$ disagree $\square \quad$ strongly disagree $\square$

2- Some of the materials used must be from real life (such as TV, magazines).

strongly agree $\square \quad$ agree $\square \quad$ undecided $\square \quad$ disagree $\square \quad$ strongly disagree $\square$

3- There must be plenty of active discussion.

strongly agree $\square \quad$ agree $\square \quad$ undecided $\square \quad$ disagree $\square \quad$ strongly disagree $\square$

4- We must spend some time 'having fun' (such as singing songs or playing games).

strongly agree $\square \quad$ agree $\square \quad$ undecided $\square \quad$ disagree $\square \quad$ strongly disagree $\square$

5- The teacher must teach us new language items (such as grammar or vocabulary).

strongly agree $\square \quad$ agree $\square \quad$ undecided $\square \quad$ disagree $\square \quad$ strongly disagree $\square$

6- The teacher must correct most of the grammar mistakes.

strongly agree $\square \quad$ agree $\square \quad$ undecided $\square \quad$ disagree $\square \quad$ strongly disagree $\square$

7- A lot of time must be spent working independently of the teacher (such as in groups). strongly agree $\square \quad$ agree $\square$ undecided $\square \quad$ disagree $\square$ strongly disagree $\square$ 
8- The teacher must often insist on correct pronunciation.

strongly agree $\square \quad$ agree $\square \quad$ undecided $\square \quad$ disagree $\square \quad$ strongly disagree $\square$

9- The teacher must guide most of what the students do.

strongly agree $\square \quad$ agree $\square \quad$ undecided $\square \quad$ disagree $\square \quad$ strongly disagree $\square$

10- The teacher must let us use our smartphones to answer her/him.

strongly agree $\square \quad$ agree $\square \quad$ undecided $\square \quad$ disagree $\square \quad$ strongly disagree $\square$ 